\title{
Free School Policy Versus Favorite School of Parents' Choice
}

\author{
Arliansyah $^{1 *}$, Muslimah ${ }^{2}$ \\ ${ }^{1}$ Doctoral Program in Social Sciences and Political Sciences, University of Muhammadiyah Malang \\ ${ }^{2}$ Lecturer of Islamic Religious Education in Postgraduate of Palangka Raya State Islamic Institute \\ *Corresponding Author: Arliansyah, Doctoral Program in Social Sciences and Political Sciences, \\ University of Muhammadiyah Malang
}

\begin{abstract}
The purpose of this study is to analyze the Indonesian government's policy on free schools versus the favorite schools of parents'choices that tend to be identical with high school fees, highlighting on how government policies in creating justice and equitable quality of education and meeting parents' needs to get quality schools for his son. The research data collection was carried out by the literature method and listening method. While the analysis uses the equivalent method and participatory methods. The results of this study are: The efforts of the Indonesian government to make free school policies to basic education to provide equitable quality of education and the opportunity to obtain education. Even though it has constraints in its implementation, but the positive impact is still felt for parents. Favorite school criteria set by parents differ, namely: because the quality of graduates is able to compete for higher school, academic and non-academic achievements, adequate infrastructure, and also because they are provoked by the term itself.
\end{abstract}

Key words: Free Schools, Favorite Schools, Parents' Choice, Education

\section{INTRODUCTION}

The free school program launched by the Indonesian government, as a continuation of the compulsory education to junior high school, there are even certain districts that have issued regional regulations that make compulsory education until senior high school(Asyiah, 2017), it becomes the answer to the mandate of Article 31 of the 1945 Constitution which is the right of the Indonesian people to obtain education.

Although the education budget is budgeted for $20 \%$ of the national budget, it still has not had a satisfying impact on the community as users of quality and free education. On the one hand, the government is helped by privately run education, but if it is not protected then education capitalism can occur. This has already been felt by the community, because some people choose quality private schools, which tend to be high cost but are considered able to meet the educational needs of their children.

The practice of parents choosing a quality school when the new student registration season is fair, because it certainly has a strong reason. For example, because the output of graduates has been proven to be able to compete with graduates of other schools, complete the resources of educators and educational staff, complete infrastructure, or because of academic and non-academic achievements. This happened because the school was trying to equip it to meet market needs.

Although the government has tried to equalize and provide educational opportunities, one of them is through zoning of recruiting new students, but because some parents have certain criteria in choosing a school, making the choice is aimed at a particular school, in society it is called a favorite school. However, not all parents have logical reasons for choosing a favorite school as mentioned above, but there are also parents who are provoked by the label of a favorite school, even though the quality is not necessarily according to need. Because expensive schools may not be able to answer the future needs of children.

How is the consequence of government policy through its programs to help equalize quality and free education in Indonesia with the fact that quality schools and low-cost favorites of parents are still difficult to obtain? This collaborative research between university in Palangka Raya - Central 
Kalimantan and Malang - East Java responded to this fact / phenomenon by raising the research title "Free School Policy Versus Favorite Schools of Parents' Choice".

\section{LITERATURE REVIEW}

\subsection{Favorite Schools as Educational Units}

The word "favorite" in the Sociology Dictionary means: the manifestation of special attention to a person, group or idea based on taste, which arises when faced with a choice. Indonesian people in their daily lives equate the notion of the word "favorite" with the word "quality". For example favorite schools, what is meant is quality schools(Soekanto, 1983).

According to Amin Widjaja Tunggal(1992)that quality is conformity/ compatibility with applicable specifications and standards; fit/ fit to use (fitness for use); can satisfy the wants, needs and rewards of customers at competitive prices. This opinion is more appropriate if it is used in the world of education, because it is not only focused on hardware, but also leads to educational software.

The above understanding is in line with Sagala(2009), that the quality of education is a picture and overall characteristics of education services both internally and externally that demonstrate their abilities, satisfy the expected needs, or that implies education inputs, processes and outputs. The quality of education is not only determined by the school as a teaching institution, but also adjusted to what the views and expectations of the community tend to always develop along with the times. The community's assessment of the quality of school graduates continues to grow.

According to Sudarmawan Danim(2006), quality schools are characterized by: a focus on internal and external customers; prevent problems by working correctly; have a resource investment; have a strategy to achieve quality; managing complaints as feedback; has a short-term, medium-term and long-term policy; involve everyone according to the task in the process of repair vertically and horizontally; encourage creativity and create quality; exercise clear control; put the quality achieved to achieve the next quality; and, view quality as an integral part of work culture.

\subsection{Parental Involvement in Education}

Parents are: people who are considered old (smart, clever, expert); adoptive parents of men and women who become a father and mother of a person based on customary law or law; foster parents of people who pay for (school) children who are not their own children on humanitarian grounds(Shaleh, 2004). According to the general formulation of the Republic of Indonesia Government Regulation No. 27 of 1990 concerning Pre-school Education, that: "parents are the father and/ or biological mother or guardian of the student concerned". This understanding shows that parents are not only due to a nasab/ offspring relationship between parents and children, but anyone who is made an elder and is responsible.

Anyone who has the status of a parent is obliged to live, education, supervision, responsibility, worship and social activities of the child until he is an adult, without leaving aside other factors that also influence the child's growth and development(Muslimah, 2015).However, as stressing the importance of the role of the family in which parents are responsible for the formation of children, so that they can later survive and find a good way to achieve the desired goals(MS, 2005).

There are a number of functions of parents for their children, especially in education, such as: first and foremost educators for children(Ulwan, 2012). Parents are the first school from which children get good grades or vice versa(Buseri, 2014).

As an implementation of the responsibilities of parents in children's education, in addition to providing education in the family, also seeking formal education(Muslimah, 2015). In the National Education System Law No. 20 of 2003 Article 1 paragraph (11) states "Formal education is a structured and tiered education pathway consisting of basic education, secondary education and higher education. This should be done by parents to their children because they are included in the compulsory education program as stated in Article 1 paragraph (18). Furthermore concerning the Rights and Obligations of Parents Article 7, paragraph (1) Parents have the right to play a role in selecting educational units and obtain information about the development of their children's education; (2) Parents and children of the age of compulsory education, are obliged to provide basic education to their children. 
Based on the Education System Law above, parents in Indonesia are obliged to enroll their children in formal schools at the age of compulsory education, and it is the right and role of parents to choose schools that fit the criteria chosen by parents for their children.

\section{Method}

Data collection in this study uses a critical approach, namely discourse as power and strength, as well as looking at people's relationships and thoughts(Asher \& Simpson, 1994). This approach understands discourse as a social practice, which in practice always has the purpose of discourse including the purpose of making free school policies and the purpose of choosing a favorite school for parents. If this happens, then the practice of discourse will display the effect of power that results in an imbalance, in this case the Indonesian government's policy of free schooling at the level of primary school education that is favored by parents. The data in this study were obtained using the literature method, which was obtained through written sources(Subroto, 1992).

This method is carried out by gathering information about the Indonesian government's policies in implementing free basic education as an effort to equalize and provide opportunities for education. In addition, researchers also use the method of watching, which is observing information from various mediaabout the development of parents who hunt for the best school for their child(Sudaryanto, 1993). Furthermore, the authors analyze this research data using the matching method, which describes the context of government policy on free schools. Also using participatory methods, about the attitudes and thoughts of parents in choosing a school for their children, which can be done through the placement of researchers as participants in the process of social transformation, in this case the researchers put themselves as recipients of information interpreting government policy with the discourse of parents choosing favorite school.

\section{Analysis of Free School Policy Versus Favorite Schools Choice Of Parents}

A reality in Indonesia if the strata of the community in responding to educational institutions as a continuation of study, consists of three layers, namely 1) not concerned about finacial to get quality schools; 2) selective to be able to quality with low costs, usually hunting quality government / public schools; and 3) surrender to government schools that are free or very low cost especially for primary education.

Responding to the above reality, the government through its education policy with the enactment of Law Number 32 of 2004 concerning regional governance has an impact on management in the region. One side of the policy of education autonomy is very positive influence on the development of schools based on the needs and challenges faced. However, due to the diversity of potential educational resources in the area, the quality of output varies. Therefore, regional and national quality standards are the main factors that must be considered in the efforts of quality a assurance or quality assurance of education.

Speaking of the quality of education, quality control of education in Indonesia until now still can not show the existence of quality institutions. The Ministry of National Education develops an Education Quality Assurance and Improvement System (SPPMP). One component of the SPPMP is school monitoring by the district government which began in 2009. The purpose of school monitoring by the district government is to improve the quality of school monitoring carried out by the District Education Office, and school supervisors in each district in Indonesia, so that the information obtained can be used effectively to improve the quality of education in schools. Research results from Kusnandimentions the steps in implementing school monitoring by the district government in Indonesia, namely: a) preparing technical guidelines for monitoring implementation by the district government, b) testing the technical guidelines for monitoring implementation, c) reviewing technical guidelines for monitoring implementation, d) implementing them nationally. School monitoring by the district government can be through School Self Evaluation which is an assessment to review the suitability of school performance with school plans that have been developed according to the National Education Standards.

Meanwhile, the free school policy that is expected to touch the goals of which is that even distribution of education experiences many obstacles in its implementation. For example: 1) some schools charge parents for contract teacher salaries; 2) ineffective communication of policy objectives; 3) The available human resource sum is optimal enough to implement the policy, but still lacking for 
implementing the budget; 4) has no clear SOP policy. The other side is found: 1) the results of the implementation of the objectives of free education regulation have been achieved by the optimal use of funds and human resources for policy implementation; 2) free education policies that are sufficient to meet the needs of the community in education; 3) the free distribution of free education; 4) the community supports the implementation of free education regulations.

Finally, the government issued Government Regulation No. 23 of 2014 regulating changes in the authority of secondary and senior secondary schools which were ultimately under the provincial government in Indonesia. Previously, sharring in managing the budget between the city/ regency and provincial governments. Budgeting is also sought to coordinate through the Financial and Development Supervisory Agency, so that the free school budget can be channeled through the right mechanism.

When juxtaposed with educational policies outside of Indonesia, for example in Pakistan, Abdul Ghafoor Awan's research results said(2015),

The quality of education continues to decline even though the government is trying to improve the quality \& quantity by introducing free education. However, most parents prefer high-cost private schools to government schools. This is because private schools are considered to be of higher quality \& have a clear socioeconomic status, meet needs, broader school access, school fees are relatively in accordance with the ability of the community, are competitive, and available job opportunities.

Different from the reality of education in Arab countries,Faisal Alsauidi(2016) in general, parents in Riyadh Saudi Arabia did not question the cost of school, this is because their economic situation was at the top level, and educational institutions provided by the private sector were their favorites because they were considered in accordance with the selection criteria. Parents choose a quality school as described in the following picture:

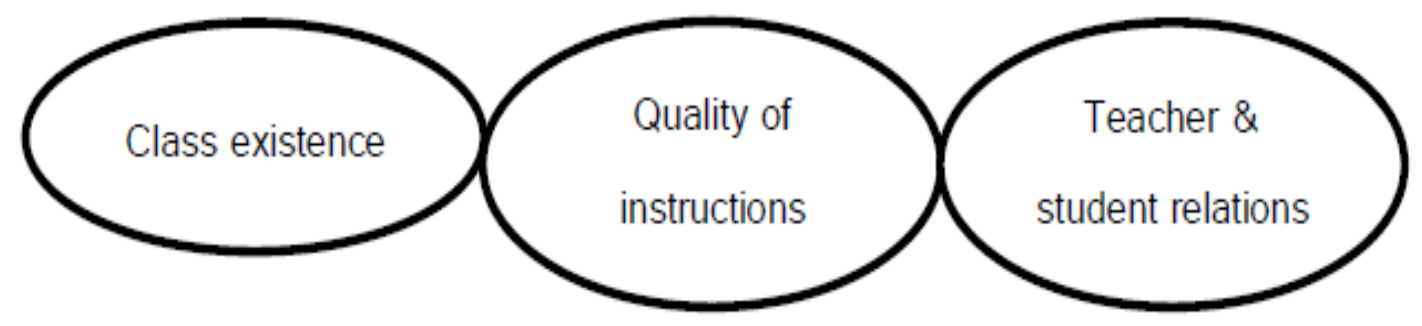

The favorite school choice for parents in Riyadh Saudi Arabia above chose because of quality: class presence (school area \& class size, school geographical location); instructional quality (quality of learning, homework, school attendance, which is indicated by the child's achievements/ final grades); and, teacher and student relationships (emotional relationships, positive teaching, passion for teachers and students in completing learning tasks, educational climate in the classroom, mutual respect, humor that increases children's self-esteem(Alsauidi, 2016).

Likewise in Indonesia, increasing demand in education, while government capacity is limited, makes private education increasingly participating as providers of education in various models. Privatization of private education is usually rooted in a liberal perspective, they often criticize a centralized education system because it is largely inefficient. The liberal view assumes that the private or private party as the provider of education that operates will give parents a choice, and that competition will lead to ever-increasing quality standards as desired by parents. While the Indonesian government generally aims to supply education as a public need for its population, referring to UNESCO as an organization engaged in education internationally.

As a developing country, education managed by the government also refers to UNESCO, but without leaving the culture of the archipelago. Education in Indonesia is also no longer centralized as is often criticized by liberal thinkers, because the Indonesian government has provided space in each region to include local potential as learning material in schools, and education provided by the Indonesian government (public schools) is still in great demand by society in general, especially those who are from the middle to lower economy. However, for some people, especially those with middle to upper economics, they prefer to choose a quality private school that meets the criteria of parents and children (Arsita, Nurhadi, \& Budiati, 2015)(Saputra, 2015).Especially for Muslim parents more likely 
to choose religious and religious schools(Arsita, Nurhadi, \& Budiati, 2015), having the status of public or private with the ability to risk costs, mileage and others (Saputra, 2015).

\section{CONCLUSION}

The Indonesian government makes a free school policy to provide equal distribution of quality education and opportunities for education. Even though it has constraints in its implementation, but it still feels a positive impact in its development, and continues to look for solutions from the implementation gap of free schools visrsus favorite schools that tend to be high-cost. Favorite schools for parents are more filled with private educational institutions because they are more heterogeneous, it is possible to meet the needs of students and parents. The criteria for favorite schools chosen by parents differ, some are due to the quality of graduates who are able to compete for higher schools, have a lot of academic and non-academic achievements, adequate infrastructure, but there are also because they are provoked by favorite terms and only participate just follow along.

The Indonesian government should continue to strive to improve the quality of education through equitable distribution of the education budget and increasing the resources of educators and education personnel. Parents have the right to choose their favorite school according to logical criteria, and should not be provoked just because the label of a favorite school or because they are part of it.

\section{REFERENCES}

[1] Alsauidi, F. (2016). International Journal of Research in Education and Science. 02(01).

[2] Arsita, M., Nurhadi, \& Budiati, A. C. (2015). Sosialitas. Jurnal Ilmiah Pendidikan Sosial Antropologi FTIK Universitas Sebelas Maret.

[3] Asher, R., \& Simpson, J. (1994). The Encyclopedia of Language and Linguistics. Oxford: Pergamon Press.

[4] Asyiah, S. (2017). Journal of Public Sector Innovation, 02.

[5] Awan, A. G. (2015). Comparative Analysis of Public and Private Educational Institutions: A case study of District Vehari-Pakistan. Journal of Education and Practice, 16.

[6] Buseri, K. (2014). Dasar Asaz, dan Prinsip Pendidikan Islam. Yogyakarta: Aswaja Pressindo.

[7] Danim, S. (2006). Visi Baru Manajemen Sekolah: Dari Unit Birokrasi Ke Lembaga Akademik. Jakarta: PT Bumi Aksara.

[8] MS, W. (2005). Perubahan Sosial dan Pembangunan. Jakarta: PT Hecca Mitra Utama.

[9] Muslimah. (2015). Penanaman Nilai Religious dalam Keluarga. Banjarmasin: IAIN Antasari Press.

[10] Sagala, S. (2009). Manajemen Strategik Dalam Peningkatan Mutu Pendidikan: Pembuka Ruang Kreatifitas, Inovasi, Dan Pemberdayaan Potensi Sekolah Dalam Sistem Otonomi Sekolah. Bandung: Alfabeta.

[11] Saputra, A. (2015). Motivasi Orang Tua Menyekolahkan Anak Ke Sekolah Islam Terpadu (Studi Pada SDIT-Al-Madinah Kota Pekanbaru). JOM FISIP IPI.

[12] Shaleh, A. R. (2004). Madrasah dan Pendidikan Anak Bangsa. Jakarta: PT Raja Grafindo Persada.

[13] Soekanto, S. (1983). Kamus Sosiologi. Jakarta: Rajawali.

[14] Subroto, E. (1992). Pengantar Metoda Penelitian Linguistik Struktural. Surakarta: Sebelas Maret University Press.

[15] Sudaryanto. (1993). Metode dan Aneka Teknik Analisis Bahasa, Pengantar Penelitian Wahana Kebudayaan secara Linguistis. Yogtakarta: Duta Wacana University Press.

[16] Tunggal, A. W. (1992). Activity Based Costing Suatu Pengantar. Jakarta: Rineka Cipta.

[17] Ulwan, A. N. (2012). Pedoman Pendidikan Anak dalam Islam. Solo: Insan Kamil.

\section{AUTHORS' BIOGRAPHY}

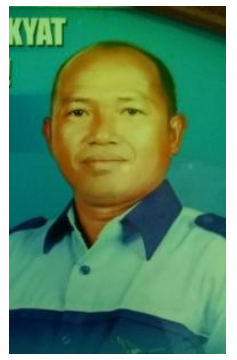

Arliansyah, M.Pd.I, Lecturerat The University of Muhammadiyah Palangka Raya. Doctoral Student of Social and Politics Faculty at theUniversityof Muhammadiyah Malang. 


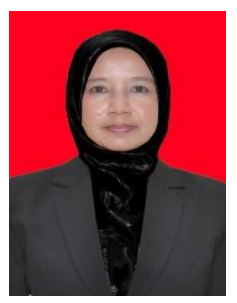

Dr. Muslimah, S.Ag., M.Pd.I, Lecturer at State Islamic Institute of Palangka Raya. Graduated from Doctoral Studies of Islamic Education Faculty at University Antasari Banjarmasin

Citation: Arliansyah, Muslimah. "Free School Policy Versus Favorite School of Parents' Choice" International Journal of Humanities Social Sciences and Education (IJHSSE), vol 7, no. 6, 2020, pp. 1-6. doi: http://dx.doi.org/10.20431/2349-0381.0706001.

Copyright: () 2020 Authors. This is an open-access article distributed under the terms of the Creative Commons Attribution License, which permits unrestricted use, distribution, and reproduction in any medium, provided the original author and source are credited. 